\title{
Scheduling Optimization of Sugarcane Harvest Using Simulated Annealing Algorithm
}

\author{
Eka Nur Afifah ${ }^{1}$, Alamsyah ${ }^{2}$, Endang Sugiharti ${ }^{3}$ \\ ${ }^{1,2,3}$ Department of Computer Science, Faculty of Mathematics and Natural Science, \\ Universitas Negeri Semarang, Indonesia \\ Email: ${ }^{1}$ ekanurafifah004@ @students.unnes.ac.id, ${ }^{2}$ alamsyah @ mail.unnes.ac.id, \\ 3endangsugiharti@mail.unnes.ac.id,
}

\begin{abstract}
Scheduling is one of the important part in production planning process. One of the factor that influence the smooth production process is raw material supply. Sugarcane supply as the main raw material in the making of sugar is the most important component. The algorithm that used in this study was Simulated Annealing (SA) algorithm. SA capability to accept the bad or no better solution within certain time distinguist it from another local search algorithm. Aim of this study was to implement the SA algorithm in scheduling the sugarcane harvest process so that the amount of sugarcane harvest not so differ from mill capacity of the factory. Data used in this study were 60 data from sugarcane farms that ready to cut and mill capacity 1660 tons. Sugarcane harvest process in 19 days producing 33043.76 tons used SA algorithm and 27089.47 tons from factory actual result. Based on few experiments, obtained sugarcane harvest average by SA algorithm was 1651.63 tons per day and factory actual result was 1354.47 tons. Result of harvest scheduling used SA algorithm showed not so differ average from mill capacity of factory. Truck uses scheduling by SA algorithm showed average 119 trucks per day while from factory actual result was 156 trucks. With the same harvest time, SA algorithm result was greater and the amount of used truck less than actual result of factory. Thus, can be concluded SA algorithm can make the scheduling of sugarcane harvest become more optimal compared to other methods applied by the factory nowdays.
\end{abstract}

Keywords: Scheduling, Harvest Scheduling, Simulated Annealing

\section{INTRODUCTION}

Scheduling is a process of allocating resources to select a set tasks within certain period [1]. Scheduling is one of the most important part of production planning process. In general, the purpose of scheduling is to optimize the use of resources so that the goals can be achieved maximally. One of the purpose of scheduling process is to reduce the delayed time of a work [1]. Scheduling must be arranged systematically with the existing resources with effective and efficient so that the goals can be achieved maximally [2]. The problems of scheduling can be solve by using exact and heuristics algorithm. One of the heuristics algorithm is Simulated Annealing (SA).

Simulated Annealing first introduced by Metropolis et al. in 1959. This algorithm addapted annealing process in manufacture crystal of a material. The apability of SA algorithm to accept bad solution or no better within certain time distinguish it 
from another local search algorithm [3]. SA algorithm has been used widely in solution optimization. In production process scheduling, result of SA algorithm with initiation used Earliest Due Date (EDD) known to increase effectiveness by minimizing maximum tardiness [4].

Production process must be done immediately for undurable resources. One of the undurable resources is sugarcane, which is one of the main raw material in making sugar. Harvest time is not carried out through the whole year but only on July to October. In that period factory must milling the sugarcane that have been cut. The cutting sugarcane must be deliver to the factory immediately and milled, because if milling process delayed will make the making of crystallization or decomposition and acidification of the sugar became difficult [5].

Delayed sugar cane milling process could make greater yield shrinkage compared to the loss in the alocating process [6]. So that the factory needs to maintain the sufficient of the raw material supply thus factory did not stockout (materials vacancy) [7]. The ideal sugarcane amount that goes on an factory is adjusted with factory capacity and the addition of $14 \%$ of factory milling capacity as supplies for te mill in the first 3 hours the next day [6]. If the amount of sugarcane that goes into the factory is too much, then it will became stored too long and cause too much loss of it yields. It is therefore necessary repair so that the amount of sugarcane that goes into the factory in accordance with the milling capacity and avoid sugarcane became too long stored. Scheduling model can improve the efficiency process of transport sugarcane harvest [8].

The problem of this study was how the use of simulated annealing algorithm to solve the problem of scheduling sugarcane harvest which the most optimal and the effectiveness and efficiency of the SA algorithm uses on the outcome of the scheduling process of sugarcane harvest. Aim of this study was to implement SA algorithm in the problems of scheduling sugarcane harvest and determine the effectiveness and efficiency Simulated Annealing algorithm in determining the scheduling of sugarcane harvest.

\section{METHODS}

\subsection{Simulated Annealing Algorithm}

Simulated Annealing Algorithm (SA) was first introduced by Metropolis et al. in 1959. The advantages of simulated annealing compared to other methods is the ability to avoid the trap of local optimal [9].

SA algorithm has four components are as follows [10]:

1. Cooling Schedule

In SA algorithm, the cooling schedule is a very critical component. This component consists of:

a. Initial Temperature

Determination of temperature of the SA are used as control parameters that must be defined carefully [11]. 


\section{b. Final Temperature}

Final temperature that reach 0 could make SA goes very long, especially when it uses geometric cooling schedule. Therefore, the stopping criteria may as the lower temperature within certain limits or when it has been frozen at current temperature with no one state that can be selected.

c. Temperature Decrement

A way of process temperature decrement geometrically (geometric decrement) with the formula

$T_{t}=\alpha T_{t-1}$

With $T_{t}$ is temperature when $\mathrm{t}$ and $T_{t-1}$ is temperature when $\mathrm{t}-1$ where $\alpha<1$. And $\alpha$ as coefficient control in temperature decrement process [12].

d. The Number of Iterations at Each Temperature

The number of used iterations must constant or dynamic. The decrement will be done if the temperature has reached a certain number of iterations.

2. The Cost function

There are several ways to measure the quality of the solution. In general, the quality of the solution was measured using a cost function. Few ways to determine a good cost function are:

a. Ensuring these functions could represent the problems.

b. The cost function should have the computational complexity as low as possible, because these functions should be calculated on each iteration.

c. The cost function must be designed so that the function can guide the search process.

3. Structure Adjacency

When performing a search process, to move from one state to another until the solution found it is necessary to define a membership structure (neighborhood). Thus, any state that can be reached from current state will be obtained.

4. Solution Space

The smaller solution space, the less the number of iterations required to converge the optimal solution. Restrictions in the search only on valid solution can narrow the solution space, and the adjacency structure can also be made as small as possible. Thus, the search for a solution can be accelerated, but the circumstances could lead to a limited increase in the quality of the solution significantly.

The design of SA algorithm, for some problems starting from defining the initial solution of the existing problems and environmental solutions, a method for calculating the value of the objective function, the cooling scheme/temperature decrement, and discharge criteria [13]. Flowchart simulated annealing algorithm can be seen in Figure 1. 


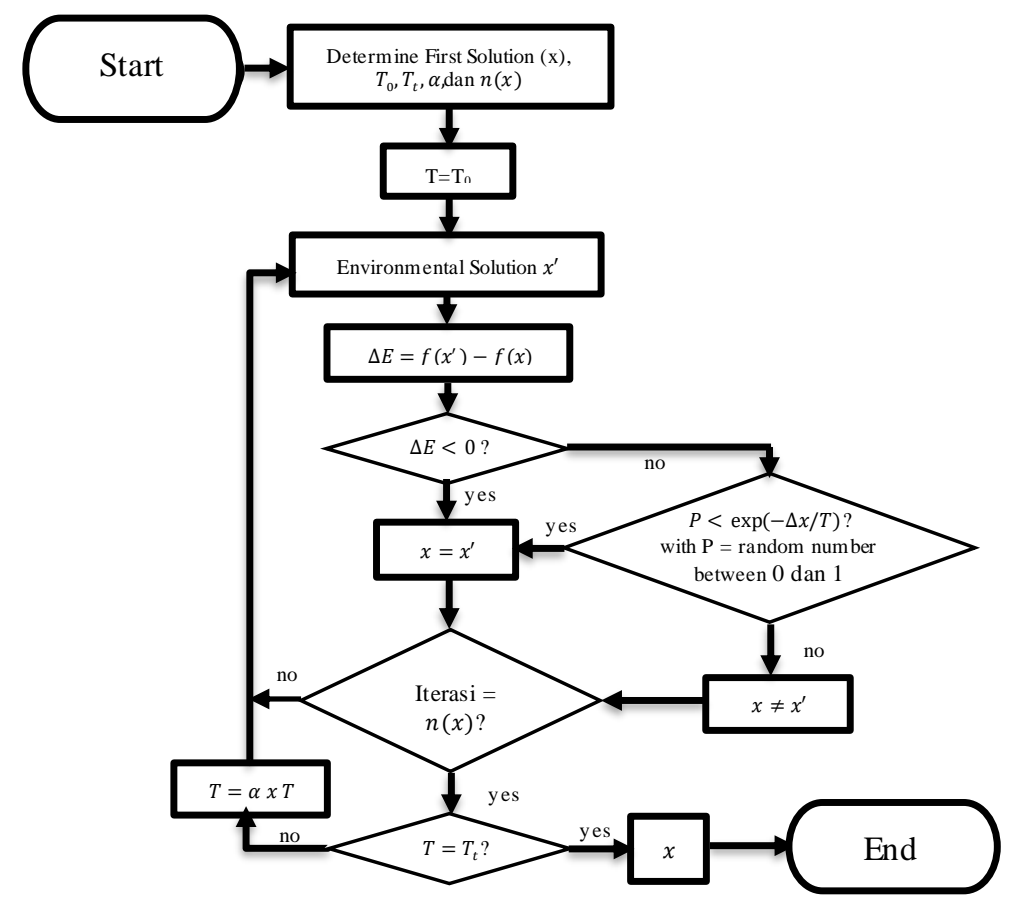

Figure 1. Simulated annealing algorithm

\section{a. Data Collection Phase}

Data collection phase is the initial stage after the preparation phase complete were carried out to obtain the data required in a related study [14]. Data collection is done through literature studies, interviews and data collection in Sugarcane Factory (SF) Pangka. Literature study aimed to find out the information about the study that will be performed. Interviews were conducted with the Head of Quality Control of SF Pangka. Data collection was performed within a month. Data taken was data on assessment by March period 2016-2017 for data sugarcane farm with categories early ripening and data of incoming sugarcane scales.

\section{b. System Development Phase}

Development scheduling system of sugarcane harvest using SA algorithm carried out with the development of the model waterfall. The model waterfall is divided into 4 interlinked stages.

1) Analysis (Requirements Analysis)

The analysis consists of the analysis of hardware requirements, software requirements, user needs and regulations analysis process [15]. Functional regulation which must be fulfill include the purpose, scope, perspective, functionality, characteristics of the user, interface and database. And nonfunctional regulations include the criteria, constraints, limitations, and performance of the software [16]. 
2) Design

Application design is not only the interface, but consists of algorithm design, architectural software design, databases, concepts design, and structures design.

3) Implementation

This stage is the translation phase of the program design has been made into order form that can be understood by computers [17].

4) Test (testing)

Stage of testing involves verifying that each unit has fulfill its specifications

[18]. At this stage, testing the errors that exist in making the program [19].

\section{c. Maintenance Phase}

The purpose of the maintenance phase is to maintain the equipment or systemthat has been created in order to be in the best condition [20].

\section{RESULTS AND DISCUSSION}

The data used in this research was assessed by March SF Pangka Tegal period 2016-2017. Data taken from the farm was one in the category of early ripening as many as 60 data of sugarcane farm were ready to harvest and data of incoming sugarcane scales. The length of harvest time determined by the amount of incoming sugarcane. From these data, resulting scheduling of sugarcane harvest for 19 days.

In scheduling problem there was limitation to determine the validity of a solution. Limitations in scheduling of sugarcane harvest, were:

Hard constraint

1. Farm with same code not allowed scheduled in one day.

2. The amount of sugarcane that will harvest should not exceed 2000 tons per day.

Soft constraint

1. Number of trucks should be kept as little as possible in order to transport the cutted sugarcane in each farm.

2. Each truck has a maximum amount in transporting sugarcane depend on the category of distance from the farm to the factory.

The steps performed in the scheduling of sugarcane harvest used SA algorithm as follows:

1) Data Entry

Data entry sugarcane farm, data skw, and data trip. In input sugarcane farm, there were distance and number of harvest days. Farm distance used to determinae how many trucks will be used in the process of transport sugarcane to the mill. While the number of harvest days used to divide the sugarcane farm into sections so that the same farm will not be scheduled in one day. Data trip consist of trip code, the farm distance to the factory and number of the trips to transport sugarcane by the trucks. 


\section{2) Parameter Entry}

Selection of parameters is important in the successful implementation of SA algorithm. Parameters that are used to complete the scheduling of sugarcane harvest used algorithm SA with the initial temperature $=1000$, final temperature $=50$, the cooling rate $=0.95$, the number of iterations $=10$.

3) Formation Initial Schedule.

The formation of the initial schedule will be used as a reference for the next iteration. The number of sugarcane harvest days determined based on the total sugarcane that will be harvested divided by the capacity of the factory. In the formation of the schedule, there was some limitations to be aware that there can be no farm with the same code was scheduled in one day and the amount of harvest in one day may not exceed 2000 tons .

4) The formation of the new schedule is done by rearranging the initial schedule previously formed randomly.

5) Assessing the solutions of random calculations results, if appropriate and feasible, then outcome calculation [22]. Objective difference calculation will produce a value that will be used to determine new schedule, that formed accepted or rejected. Objective value calculation formula $\Delta E=f\left(x^{\prime}\right)-f(x)$ with $f\left(x^{\prime}\right)$ is a function of the value of environmental solutions $x^{\prime}$, and $f(x)$ is the function value of the solution now $x$. Objective value used is the amount of sugarcane will be harvested on each day.

If the result of the difference in objective value $<0$ then the schedule that formed will be accepted as a schedule. If the difference in objective value $>0$ then there are two possibilities by comparing the value of $\exp \left(-\frac{\Delta E}{T}\right)$.

6) Calculating random value $[0,1] P=\exp \left(-\frac{\Delta E}{T}\right)$ when $\Delta E$ not accepted. The new schedule will be accepted if the value of $r$ (random numbers between 0 and 1) $<\exp \left(-\frac{\Delta E}{T}\right)$ and the new schedule will be rejected if the value of $r \geq$ $\exp \left(-\frac{\Delta E}{T}\right)$. Obtained decision new schedule is accepted or rejected.

7) Checking the iteration has reached $n(x)=10$. If not then returned to the step (4).

8) Checking whether the temperature has reached the termination criteria or not. If the temperature has not reached the minimum temperature (50), then temperature is decrease using aparameter cooling rate $(\alpha)$. Formulas temperature drecement is $T_{n}=T_{n-1} \times \alpha$. After the temperature decrease, returning to the step (4). If it is reached, then stop.

9) The process has been completed and obtained the best schedule. Best selected schedule is the schedule with the smallest difference sugarcane amount and sugarcane harvest no more than 1900 tons. The process of determining the schedule randomly causes scheduling sugarcane harvest result not the same on every program.

Based on the harvest scheduling that has been done by the system, the harvest result for 19 days is presented in Table 1 compared to factory results. From few 
experiments, proved that SA algorithm can generate schedules that approached the factory milling capacity. Therefore, delayed in production due to shortages of raw materials can be minimized. Although the harvest results was fluctuated, but the results was still tolerated because was not so differ from the factory milling capacity. The highest of factory harvest results was 1988.3 tons and the lowest was 692.9 tons. Scheduling results from SA algorithm obtained the highest harvest was 1781.28 tons, while the amount of the lowest was 1554.13 tons.

Table 1. Results comparis on of algorithms SA and factory results

\begin{tabular}{ccccc}
\hline \multirow{2}{*}{ Day } & \multicolumn{2}{c}{ Factory Results } & \multicolumn{2}{c}{ SA Algorithm Results } \\
\cline { 2 - 5 } & Harvest(ton) & Truck & Harvest(ton) & Truck \\
\hline 1 & 750,0 & 97 & 1650,89 & 119 \\
2 & 902,8 & 108 & 1650,89 & 119 \\
3 & 692,9 & 89 & 1652,24 & 117 \\
4 & 1138,7 & 117 & 1696,68 & 125 \\
5 & 1233,6 & 145 & 1646,00 & 119 \\
6 & 1153,1 & 145 & 1716,36 & 129 \\
7 & 945,9 & 144 & 1781,28 & 130 \\
8 & 1430,5 & 162 & 1676,06 & 128 \\
9 & 1438,8 & 151 & 1676,06 & 128 \\
10 & 615,0 & 78 & 1554,13 & 117 \\
11 & 1807,0 & 191 & 1645,54 & 117 \\
12 & 1988,3 & 223 & 1690,98 & 123 \\
13 & 1918,8 & 218 & 1691,39 & 121 \\
14 & 1575,4 & 202 & 1631,93 & 118 \\
15 & 1472,5 & 129 & 1663,81 & 113 \\
16 & 1759,6 & 205 & 1585,36 & 105 \\
17 & 1275,6 & 162 & 1586,56 & 110 \\
18 & 1973,2 & 199 & 1578,17 & 111 \\
19 & 1663,3 & 201 & 1606,67 & 118 \\
\hline
\end{tabular}

Based on Table 1, sugarcane harvest results comparative presented in a line diagram that can be seen in Figure 2 and the results of comparis on of trucks each day presented a line chart that can be seen in Figure 3.

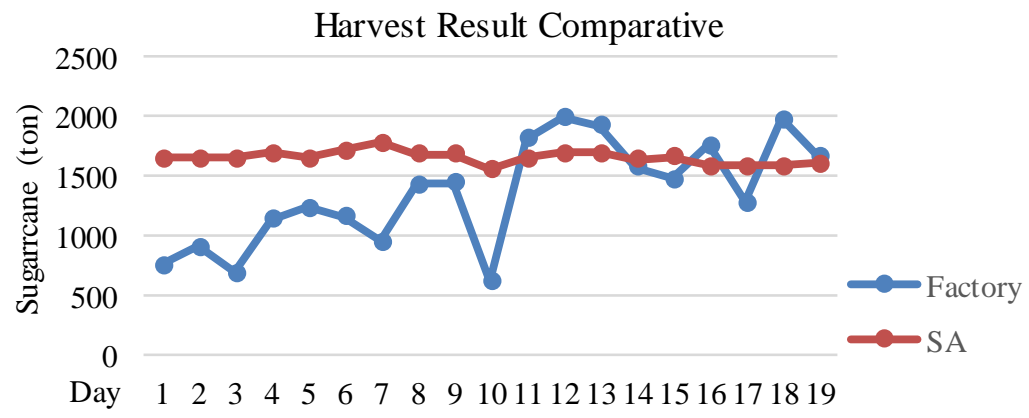

Figure 2. Graphics of harvest results comparison 


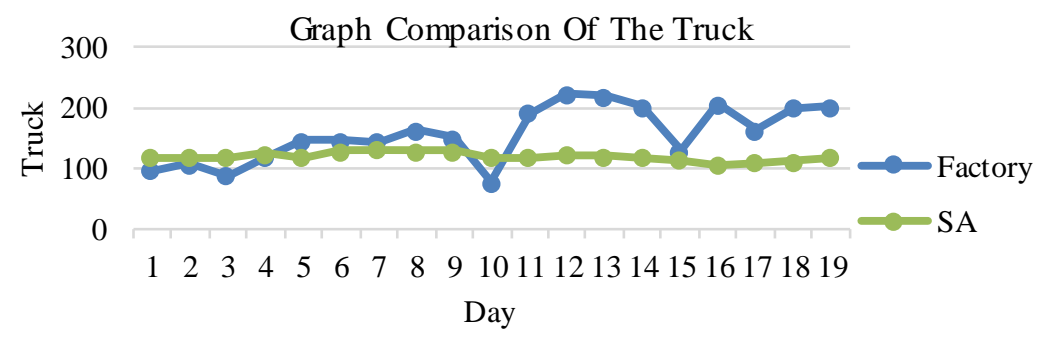

Figure 3. Graph of comparison of the used truck

Harvest results comparison graph above shows the harvest scheduling SA algorithm produced not so differrent sugarcane harvest per day from the factory milling capacity. Thus avoiding the sugarcane that went too much (can reduce the amount of sugarcane yield and quality of sugar that produced) and avoid incoming too little sugar (avoid factory ceased operations resulting in loss of the factory). Therefore, the use of SA algorithm help in scheduling of sugarcane harvest so that the results obtained stable in each day and in accordance with the factory milling capacity.

Graph of comparis on of the truck in Figure 3 indicates the use of the truck based on the scheduling algorithm SA every day not so differrent. That was because each of the sugarcane farm set number of trips on each truck by taking into account the distance between the farm with a factory. Determination of the trips number was useful to clarify the number of trips on each truck and save the use of trucks to transport the harvest result.

SA algorithm can be done to schedule sugarcane harvest by considering the amount of sugarcane harvest so it was not differ from the factory milling capacity. With this scheduling model, restrictions the number of sugarcane harvest in each farm can be done. This is to avoid the factory stop operating when the incoming sugarcane in factory too little and avoid losing a lot of sugarcane yield when the coming sugarcane in factory too much. The results of SA algorithm compare to factory actual results for 19 days can be seen in Table 2 .

Tabel 2. Comparison of the results with the results of the SA algorithm factory

\begin{tabular}{lrr}
\hline \multicolumn{1}{c}{ Parameter } & SA & Initial Condition \\
\hline Harvested Sugarcane (ton) & 33043,76 & 27089,47 \\
Sugarcane Average Per Day (ton) & 1651,63 & 1354,47 \\
Truck Amount Per Day & 119 & 156 \\
\hline
\end{tabular}

Factory mill capacity that used was 1660 tons, then harvest scheduling with SA algorithm produces an average which was not so differ from the factory milling capacity. The number of used trucks was not too much so it saves the use of the truck. By same harvest time, the scheduling SA algorithm produced more 
sugarcane harvest and the number of trucks that use less than the actual result of the factory. It can be concluded that the result of the scheduling harvest sugarcane used SA algorithm was more effective and efficient than the method applied by the factory nowadays.

This harvest scheduling system has advantages and disadvantages. The advantages of scheduling sugarcane harvest system with SA algorithm was able to calculate a lot of data. There was no same farm of data contained in a single day in the result. As for some of the disadvantages of this system including the data used in this study was only the farm with category early ripe sugarcane. The system was made did not take into account the costs incurred by both the SF and by factory owner.

\section{CONCLUSION}

The Implementation of SA algorithm can make the better scheduling sugarcane harvest, because the schedule selected was the one that did not have the result of harvest sugarcane more than 1900 tons (to minimize the delay in the process of milling). The process of sugarcane harvest for 19 days resulted 33043.76 tons used SA algorithm and 27089.47 tons of factory actual results. With factory milling capacity was 1660 tons, the harvest scheduling SA algorithm produced an average which did not so differ from that factory milling capacity 1651.63 tons. Scheduling the used trucks with SA algorithms produced an average of 119 trucks per day, while the factory actual result was 156 trucks. Determination of the number of truck trips at each farm based on the distance from farm to the factory help in saving the use of the truck. Thus, can be concluded SA algorithm can make the scheduling of sugarcane harvest become more optimall compared to other methods applied by the factory nowadays.

\section{REFERENCES}

[1] Baker, K.R. (1974). Introduction to Squencing and Scheduling. New York: John Wiley \& Sons, Inc.

[2] Arifudin, R. (2012). Optimasi penjadwalan proyek dengan penyeimbangan biaya menggunakan kombinasi CPM dan algoritma genetika. Jurnal Masyarakat Informatika, 2(4), 1-14.

[3] Wijayaningrum, V.N., Mahmudy, W.F., \& Natsir, M.H. (2017). Optimization of Poultry Feed Composition Using Hybrid Adaptive Genetic Algorithm and Simulated Annealing. Journal of Telecommunication, Electronic and Computer Engineering, 9(2-8), 183-187.

[4] Azmi, M.H., Sugiono, \& Tantrika, C.F.M. (2015). Penjadwalan Produksi Rokok untuk Meminimalkan Maximum Tardiness menggunakan Algoritna Simulated Annealing. Jurnal Rekayasa dan Manajemen Sistem Industri, 3(2), 353-362. Murbyarto. 1984. Masalah Industri Gula di Indonesia. Yogyakarta: BPEE.

[5] Bantacut, T., Sukardi, \& Supatma, I.A. (2012). Kehilangan Gula Dalam Sistem Tebang Muat Angkut Di Pabrik Gula Sindang Laut Dan Tersana Baru Cirebon. Jurnal Teknologi Pertanian, 13(3), 199-206. 
[6] Oktaviyani., Dwijanto, \& Supriyono. (2017). Optimasi Penjadwalan Produksi Dan Perencanaan Persediaan Bahan Baku Menggunakan Rantai Markov (Studi Kasus Kinken Cake \& Bakery Kutoarjo). UNNES Journal of Mathematics (UJM), 5(1), 1-16.

[7] Harison, G.I. (2012). Sistem Penunjang Keputusan Penjadwalan Transportasi Angkut Tebu. Skripsi. Bogor: Institut Pertanian Bogor.

[8] Basuki, H. \& Santosa. (2004). Modeling Dan Simulasi. Jakarta Selatan: IPTAQ Mulia Media.

[9] Suyanto. (2014). Algoritma Optimasi: Deterministik atau Probabilistik. Yogyakarta: Graha Ilmu.

[10] Wiktasari., \& Suseno, J.E. (2016). Metode Simulated Annealing untuk Optimasi Penjadwalan Perkuliahan Perguruan Tinggi. Jurnal Sistem Informasi Bisnis, 6(2), 133-143.

[11] Yu, V. F., Redi, A. A. N. P., Hidayat, Y. A., \& Wibowo, O. J. (2017). A Simulated Annealing Heuristic for The Hybrid Vehicle Routing Problem. Applied Soft Computing ,53, 119-132.

[12] Jaroslaw, P., Czeslaw, S., \& Domini, Z. (2013). Optimizing Bicriteria Flow Shop Scheduling Problem by Simulated Annealing Algoritm. Procedia of Computer Science, 18, 936 - 945.

[13] Sugiharti, E., Firmansyah, S., \& Devi, F.R. (2017). Predictive Evaluation Of Performance Of Computer Science Students Of Unnes Using Data Mining Based On Naïve Bayes Classifier (Nbc) Algorithm. Journal of Theoretical and Applied Information Technology, 95(4), 902-911.

[14] Ashari, I. A., Muslim, M. A., \& Alamsyah. (2016). Comparis on Performance of Genetic Algorithm and Ant Colony Optimization in Course Scheduling Optimizing. Scientific Journal of Informatics, 3(2), 149 - 158.

[15] Bassil, Y. (2012). A Simulation Model for Waterfall Software Development Life Cycle. International Journal of Engineering and Technology, 2(5), 742-749.

[16] Muslim, M.A., Prasetiyo, B., \& Alamsyah. (2016). Implementation Twofish Algorithm for Data Security in A Communication Network Using Library Chilkat Encryption Activex. Journal of Theoretical and Applied Information Technology, 84(3), 370-375.

[17] Purwinarko, A. 2014. Model Expertise Management Sistem di Universitas Negeri Semarang. Scientific Journal of Informatics, 1(2), 177-184.

[18] Sugiharti, E., \& Triliani, S. E. 2014. Perancangan Aplikasi Surat Masuk dan Keluar pada PT. Angkasa Pura 1 Semarang. Scientific Journal of Informatics, 1(1), 41.

[19] Muslim, M. A., \& Retno, N. A. (2015). Implementasi Cloud Computing Menggunakan Metode Pengembangan Sistem Agile. Scientific Journal of Informatics, 1(1), 29-37.

[20] Juangai, T., \& Hongjun, X. (2012). Optimizing Arrival Flight Delay Scheduling Based on Simulated Annealing Algorithm. Physics Procedia: International Conference on Medical Physics and Biomedical Engineering, $33,348-353$. 